\title{
In vivo and in silico Evaluation of Analgesic and Hypoglycemic Activities of Roots of Acacia nilotica, Azadirachta indica and J ustica adhatoda
}

\author{
Fahad Hussain ${ }^{1}$, Poushali Saha ${ }^{2}$, Fahad Imtiaz Rahman ${ }^{2}$, \\ Mohammad Salim Hossain ${ }^{1}$ and S. M. Abdur Rahman ${ }^{2}$ \\ ${ }^{1}$ Department of Pharmacy, Noakhali Science and Technology University, Noakhali, Bangladesh \\ ${ }^{2}$ Department of Clinical Pharmacy and Pharmacology, Faculty of Pharmacy, University of Dhaka, \\ Dhaka-1000, Bangladesh
}

(Received: November 16, 2021; Accepted: December 9, 2021; Published (web): December 26, 2021)

\begin{abstract}
The present study focuses on the investigation of methanol extracts of roots of three indigenous plants of Bangladesh namely Acacia nilotica, Azadirachta indica and Justicia adhatoda to evaluate their analgesic and hypoglycemic activities in experimental animal model along with in silico modelling of several compounds present in the root extracts of these plants. Analgesic and hypoglycemic activities were evaluated in Swiss albino mice using acetic acid-induced writhing inhibition method and glucose tolerance test, respectively. In silico molecular docking and ADME study was conducted to assess the binding affinity with the target receptors and oral bioavailability of the compounds. The methanol extracts of A. nilotica, J. adhatoda and A. indica roots at a dose of $400 \mathrm{mg} / \mathrm{kg}$ body weight reduced the number of writhes by $61.53 \%, 54.61 \%$ and $47.69 \%$, respectively compared to standard diclofenac sodium $(70.77 \%$ at a dose of $50 \mathrm{mg} / \mathrm{kg} \mathrm{bw})(\mathrm{p}<0.05)$. A. nilotica and A. indica root extracts showed significant hypoglycemic activity at a dose of $400 \mathrm{mg} / \mathrm{kg}$ bw (\% reduction of blood glucose 43.66 and $37.55 \%$ respectively, $\mathrm{p}<0.001$ ) and $J$. adhatoda root extract reduced the blood glucose level by $33.71 \%(\mathrm{p}<0.001)$ compared to that of standard drug, glibenclamide (57.46\% reduction of blood glucose) after 120 minutes of administration. Among the computationally tested compounds, flavan-3-ol showed the lowest binding energy $(-8.7 \mathrm{kcal} / \mathrm{mol})$ with both COX-1 and COX-2 compared to standard diclofenac sodium $(-7.8 \mathrm{kcal} / \mathrm{mol})$. On the other hand, quercetin demonstrated the lowest binding energy $(-8.8 \mathrm{kcal} / \mathrm{mol})$ with ATP-sensitive potassium channel with Sulfonylurea Receptor 1 subunit among the tested compounds compared to standard glibenclamide $(-9.3 \mathrm{kcal} / \mathrm{mol})$. All the compounds showed high oral bioavailability in ADME analysis. Among all the root extracts, A. nilotica exhibited the most promising analgesic and hypoglycemic activities and should be employed to future investigation for isolating specific chemical constituents.
\end{abstract}

Key words: Acacia nilotica, Azadirachta indica, Justicia adhatoda, methanol root extracts, analgesic, hypoglycemic

\section{INTRODUCTION}

The use of medicinal plants for the prevention and cure of different diseases has been in practice from the time immemorial. There is an uprising demand for the herbal drug treatment of different diseases and a variety of medicinal plants are being explored in Ayurvedic system. Numerous biologically active secondary metabolites have been discovered and identified from hundreds of medicinal

Correspondence to: S. M. Abdur Rahman

Phone: +88 (02)9661920-73, Ext. 8166 (office),

+8801732477343 (mobile);

Email:smarahman@du.ac.bd

Dhaka Univ. J. Pharm. Sci. 20(2): 185-197, 2021 (December)

DOI: https://doi.org/10.3329/dujps.v20i2.57169 plants which are paving the ways to invent safe and efficacious remedies for different ailments. ${ }^{1}$ The present estimation of herbal medicines usage for health care is about 4 billion. ${ }^{2}$ Medicinal plants are the prominent reservoir of natural molecules with multifarious pharmacological activities, which may appear as potential leads for new drugs discovery and development. Therefore, medicinal plants have attained the center of attention in research and development of new drug to reveal the facts behind their traditional uses ${ }^{3}$ and the aims of researchers are to develop of new prototypic compounds with low cost and less side effects. ${ }^{4}$ Based on the pharmacological properties of indigenous medicinal plants new herbal, Ayurvedic and Chinese medicines 
are incorporated in the market as alternative treatments for many disorders.

To explore the therapeutic potentials of indigenous plants we have been continuously investigating several prominent medicinal plants. Earlier, we have identified the medicinal properties of a number of plant extracts. ${ }^{5-8}$ Herein, we have selected three plants namely Acacia nilotica (Family: Fabaceae), Azadirachta indica (Family: Meliaceae) and Justicia adhatoda (Family: Acanthaceae) based on their traditional use and phytoconstituents. A. nilotica, A. indica and $J$. adhatoda plants under investigation are enriched in several secondary metabolites including flavonoids and phenolic compounds. The root of A. nilotica contains catechin, ethyl gallate, flavan-3-ol, betulin, octaconsanol, $\beta$ sitosterol and $\beta$-amyrin which is traditionally used in cancer, tuberculosis and induration of liver and spleen. ${ }^{9}$ For more than 4000 years, A. indica is considered as natural drug reservoir in Ayurvedic medicine due to broad spectrum of medicinal properties of all parts of this plant. Some compounds isolated from $A$. indica are quercetin, nimbin, azadirachtin, meliantriol and salannin which possess insecticidal and pesticidal activities. ${ }^{10,11} J$. adhatoda is a rich source of pyrroquinazoline alkaloids like vasicinol, vasicine, vasicinone, peganine and other constituents in minor amount. ${ }^{12,13}$ The traditional uses of this plant in the treatment of asthma, cold, cough, rheumatism, swelling and venereal diseases, joint and lumber pain, eczema, malaria etc. are found in Indian medicine. $^{14}$

In Bangladesh, different parts of the selected plants are used traditionally for the treatment of a number of health ailments. For example, leaves of $J$. adhatoda are used as antitussive medicine ${ }^{15}$, leaves and barks of $A$. indica are used against different skin infections, cancer and pests ${ }^{10,16}$, and seeds and leaves of A. nilotica possess antimalarial, antimicrobial, antidiarrheal, astringent, antihypertensive and antispasmodic properties. ${ }^{17}$ Although leaves, barks, stems, flowers, fruits and roots of the three plants have diversified ethno-pharmacological uses, there is lack of sufficient reports on the traditional uses of the root parts as they have not been investigated adequately for the biological activities. Therefore, we decided to test the analgesic and hypoglycemic properties of the roots of these plants via in vivo and in silico approaches. We selected these three plants because the root parts of these plants have not been investigated widely. In this study we aimed to investigate and compare the biological activity of the root extracts of these plants in order to determine which root had the highest potential of possessing natural lead compounds.

In silico molecular docking and ADME study are considered as reliable tools to identify active sites of the target receptors and to analyze binding interactions of compounds with the proteins along with prediction of drug like characteristics of the molecules. ${ }^{18}$ In this study, several components reported to be present in the roots of the selected three plants were analyzed for their binding affinity with the target receptors for analgesic and hypoglycemic activities. The present study concentrates on the exploration of analgesic and hypoglycemic activities of the methanolic crude extracts of the roots of three conspicuous medicinal plants namely A. nilotica, A. indica and J. adhatoda including in silico analysis of the compounds present in the roots of the plants.

\section{MATERIALS AND METHODS}

Drugs and chemicals. The solvents and chemicals were obtained from University laboratory stock. Glibenclamide was collected as Dibenol Tablet and Diclofenac Sodium as Clofenac Injection, from Square Pharmaceuticals Ltd. Bangladesh. Normal saline solution was acquired from Beximco Pharmaceuticals Ltd., Bangladesh. Tween-80 was obtained from BDH Chemicals, UK. All analytical reagent grade chemicals were used in the experiment.

Collection of plant materials. Fresh roots of $A$. nilotica and A. indica were collected from Noakhali and fresh roots of $J$. adhatoda were collected from Gazipur, Dhaka. The plants were identified in Bangladesh National Herbarium, Dhaka where voucher specimens have been deposited with the 
accession numbers as DACB-38214, DACB-38215 and DACB-38213 for A. nilotica, A. indica and $J$. adhatoda, respectively.

Preparation of extract. The collected roots of the three plants were washed, cut into small pieces and air dried and then oven dried at temperature below $30^{\circ} \mathrm{C}$ for 24 hours to facilitate grinding into coarse powder and was stored in air-tight container in cool, dark and dry place for future use. About 700gm of the powdered root of each plant was taken in three different clean desiccators (5 liters) and soaked in 2.5 liter of methanol each. The containers were covered by aluminum foil and kept for 15 days with random stirring and shaking. The extractable components of the roots in the solvent was filtered using cloth and finally with Whitman filter papers. The weights of the crude extracts of A. nilotica, A. indica and $J$. adhatoda were found to be $60 \mathrm{gm}, 35 \mathrm{gm}$ and $16 \mathrm{gm}$, respectively. After drying, the extracts were preserved in the refrigerator to prevent microbial contamination. The test doses were prepared adding the respective extract with normal saline solution and $1 \%$ Tween 80 as required.

Experimental animal. Swiss-albino mice (Mus musculus) of either sex, 4-5 weeks of age, obtained from Jahangir Nagar University Animal House, Savar, Bangladesh were used in the experiment. The animals were kept in polypropylene cages $(30 \mathrm{~cm} \mathrm{x}$ $20 \mathrm{~cm} \times 13 \mathrm{~cm})$ in standard conditions for $\left(21 \pm 1^{\circ} \mathrm{C}\right.$ with a $12 \mathrm{~h}$ light and dark cycle) seven days prior to the experiment. The animals were supplied with standard diet and water ad libitum. The experiment was performed in the Physiology Laboratory of the Faculty of Pharmacy at University of Dhaka. After completion of the experiment the mice were returned to the officer of the animal husbandry for necessary action regarding the animals.

Analgesic activity. Acetic acid induced writhing method was used to evaluate the analgesic activity $^{19,20}$. Forty mice were divided into eight groups randomly by generating random numbers using randomizing function in Microsoft Excel. Each group consisted of five mice receiving a particular treatment. Before each experiment, each mouse was weighed accurately and the doses of the test samples and control materials were adjusted accordingly. The crude methanolic extracts of $A$. nilotica, $A$. indica and J. adhatoda were administered at both doses of 400 $\mathrm{mg} / \mathrm{kg}$ and $200 \mathrm{mg} / \mathrm{kg}$ bw of mice. Diclofenac sodium was used as standard at the dose of $50 \mathrm{mg} / \mathrm{kg}$ bw and 1\% Tween 80 in normal saline at the dose of $0.2 \mathrm{ml} / 10 \mathrm{gm}$ of body weight was used as control. After 30 minutes of administration of the materials to allow proper absorption, acetic acid $(0.7 \%)$ was administered intraperitoneally at a dose of $0.1 \mathrm{ml} / 10$ gm to each animal. After 5 minutes, the number of writhing was counted for each mouse for 15 minutes. The writhing counts of the test samples and diclofenac sodium treated groups were compared to those of the animals in the control group. Percent inhibition of writhing in comparison to control group was considered as an index of analgesia and was calculated using the following formula:

$$
\% \text { inhibition }=(\mathrm{Wc}-\mathrm{Wt}) \times 100) / \mathrm{Wc} \text {, }
$$

Here, Wc denotes the average number of writhing in the control group and Wt denotes the average number of writhing in the test group.

Hypoglycemic activity. Hypoglycemic activity was studied in glucose-loaded hyperglycemic mice. ${ }^{21,22}$ Forty mice were fasted for 18 hours with free access to water and divided into eight groups randomly by generating random numbers using randomizing function in Microsoft Excel. Each group consisted of five mice receiving a particular treatment. Fasting blood glucose level was checked by collecting blood samples from tail vein. Before any treatment, each mouse was properly weighed and the doses of the test samples and control materials were adjusted accordingly. The crude methanolic extracts of A. nilotica, A. indica and J. adhatoda roots were administered at both doses of $400 \mathrm{mg} / \mathrm{kg}$ and $200 \mathrm{mg} / \mathrm{kg}$ bw of mice. The standard glibenclamide was administered at the dose of 5 $\mathrm{mg} / \mathrm{kg}$ body weight and $1 \%$ Tween 80 in normal saline at the dose of $0.2 \mathrm{ml} / 10 \mathrm{gm}$ of body weight was used as control. After $30 \mathrm{~min}$ of administration, the mice of all groups were orally treated with $10 \%$ glucose solution (zero minute) at $2 \mathrm{gm} / \mathrm{kg}$ bw. Blood 
samples were collected from tail vein just before glucose administration and at 30 minutes, 60 minutes, 90 minutes and 120 minutes after glucose loading. Blood glucose level was measured by using glucometer and glucose oxidase-peroxidase reactive strips ${ }^{23}$ and compared with the control group to calculate the hypoglycemic activity of the standard and test samples using the following formula:

$\%$ reduction of blood glucose level $=((\mathrm{Gc}-$

$$
\mathrm{Gt}) \times 100) / \mathrm{Gc}
$$

Here, Gc is the average blood glucose level in the control group and $\mathrm{Gt}$ is the average blood glucose level in the test group.

Statistical evaluation. All values from the experiments were demonstrated as the mean \pm standard error of the mean (SEM) and the results were analyzed statistically by One Way Analysis of Variance (ANOVA) followed by Dunnett's test by using SPSS (version 19, IBM Incorporation, USA). The $\mathrm{p}<0.05$ was considered to be statistically significant. The outcome assessment and the data analysis were performed blind as the analyst was not aware of the allocation of the groups.

Selection of compounds and target proteins for in silico molecular docking. Eight different compounds reported to be present in the selected plants were chosen for computational analysis of analgesic and hypoglycemic activities compared to standard glibenclamide (PubChem CID 3488) and diclofenac (PubChem CID 3033). The compounds were catechin (PubChem CID 73160), ethyl gallate (PubChem CID 13250), flavan-3-ol (PubChem CID 3707243) nimbin (PubChem CID 108058), quercetin (PubChem CID 5280343), vasicine (PubChem CID 442929), vasicinol (PubChem CID 442934) and vasicinone (PubChem CID 10242). The structures of the selected compounds were obtained from PubChem and optimized using the software package Avogadro (Version 1.2), an open-source molecular builder and visualization tool. The MMFF94 force field model was used to optimize the molecules until further optimization runs resulted in no further changes in geometry. The three-dimensional structures of the protein targets selected for the molecular docking study were obtained from the Protein Data Bank RCSBPDB ${ }^{24}$ which included cyclooxygenase-1 (PDB: 1EQG) ${ }^{25}$, cyclooxygenase-2 (PDB: 5IKT) ${ }^{26}$ for analgesic activity and ATPsensitive potassium channel with sulfonylurea receptor-1 (SUR1) subunit (PDB: 5YW7) ${ }^{27}$ for the hypoglycemic activity. The enzymes/receptor were prepared for docking by first removing all the heteroatoms and water molecules from the crystal structure using PyMol (version 2.4.1) software packages. ${ }^{28}$ Swiss-PdbViewer software packages (version 4.1.0) were used to minimize energy where computations were carried out in vacuo with the GROMOS 96 43B1 parameters set, without reaction field. ${ }^{29}$ Autodock Vina docking protocol was used using the PyRx (Version 0.8) virtual screening tool and grid box dimensions were selected based on the ligand binding site coordinates of the threedimensional structures of the protein targets obtained through PyMol. ${ }^{30}$ BIOVIA Discovery Studio Visualizer 2016 was employed for assessing the docking positions for best ligand macromolecule interactions.

\section{RESULTS AND DISCUSSION}

Analgesic activity. The analgesic activity of the methanolic extracts of the roots of three plants are summarized in Table 1. All the plant extracts showed statistically significant analgesic activity in a dose dependent manner. A. nilotica revealed potent analgesic activity with writhing inhibition of $61.53 \%$ at the dose of $400 \mathrm{mg} / \mathrm{kg}$ bw compared to standard diclofenac sodium $(70.77 \%$ writhing inhibition at 50 $\mathrm{mg} / \mathrm{kg} \mathrm{bw})$. A. indica and J. adhatoda demonstrated mild to moderate analgesic activity at $400 \mathrm{mg} / \mathrm{kg}$ bw with writhing inhibition of $47.69 \%$ and $54.61 \%$, respectively. Acetic acid-induced writhing method is mainly used for the evaluation of peripheral analgesic activity of the test samples considering reduction of writhing count as an index of peripheral analgesia. ${ }^{31}$ Acetic acid produces pain sensation by activating localized inflammatory response to secret free arachidonic acid which in turn increases $\mathrm{PGE}_{2}$ and $\mathrm{PGF}_{2 \alpha}$ in peritoneal fluid. ${ }^{32}$ It may also involve the mast cells and macrophages which secret cytokines, 
e.g. interleukin $1 \beta$ (IL-1 $\beta$ ), interleukin 8 (IL-8) and tumor necrosis factor $\alpha$ (TNF- $\alpha)$ which is also regulated by prostaglandin pathway. ${ }^{33}$ The standard diclofenac sodium is a non-steroidal antiinflammatory drug (NSAID) which acts on cyclooxygenase 2 ( $\mathrm{COX} 2$ ) enzyme to block prostaglandin synthesis causing anti-nociceptive action. The percent writhing inhibitions of the methanol extracts of the plant roots are comparable to that of the standard diclofenac sodium. So, the pain reducing activity might be because of its ability to interfere in the biosynthesis of some chemical agents such as prostaglandins and leukotrienes from cyclooxygenase and lipooxygenase pathway which are accountable for blocking pain sensation and hence exhibited promising analgesic activity.

Table 1. Screening of analgesic activity of plant extracts by acetic acid $(0.7 \%)$ induced writhing method.

\begin{tabular}{|c|c|c|c|c|}
\hline Animal group & $\begin{array}{c}\text { Test sample dose } \\
(\mathrm{mg} / \mathrm{kg} \mathrm{bw})\end{array}$ & Mean \pm SEM & $\%$ of writhing & $\%$ of inhibition \\
\hline Control (1\% Tween-80 in normal saline) & $0.2 \mathrm{ml} / 10 \mathrm{~g}$ of body $\mathrm{wt}$ & $26 \pm 0.7$ & 100 & - \\
\hline Standard (Diclofenac sodium) & 50 & $7.6 \pm 0.67 *$ & 29.23 & 70.77 \\
\hline \multirow[t]{2}{*}{ A. nilotica } & 200 & $11.4 \pm 1.02 *$ & 43.85 & 56.15 \\
\hline & 400 & $10 \pm 0.7^{*}$ & 38.46 & 61.53 \\
\hline \multirow{2}{*}{ A. indica } & 200 & $16.6 \pm 1.02 *$ & 63.84 & 36.16 \\
\hline & 400 & $13.6 \pm 0.92 *$ & 52.30 & 47.69 \\
\hline \multirow[t]{2}{*}{ J. adhatoda } & 200 & $15 \pm 0.70 *$ & 57.69 & 42.30 \\
\hline & 400 & $11.8 \pm 0.86^{*}$ & 45.38 & 54.61 \\
\hline
\end{tabular}

$\mathrm{SEM}=$ Standard error of mean. ${ }^{*} \mathrm{p}<0.001$; Probability values calculated as compared to control using one way-ANOVA followed by Dunnett's test.

Hypoglycemic activity. The hypoglycemic activity of the crude methanol extracts of the roots of A. nilotica, A. indica and J. adhatoda are summarized in Table 2 and Figure 1. All the root extracts reduced blood glucose level in a dose dependent manner. At the dose of $200 \mathrm{mg} / \mathrm{kg}$ bw, all the extracts exhibited mild to moderate reduction of blood glucose level. The crude methanol extracts of $A$. nilotica and $A$. indica roots at the dose of $400 \mathrm{mg} / \mathrm{kg}$ bw showed significant $(\mathrm{p}<0.001)$ hypoglycemic activity with $43.66 \%$ and $37.55 \%$ reduction of blood glucose level compared to standard glibenclamide $(57.46 \%$ reduction of blood glucose level at $5 \mathrm{mg} / \mathrm{kg} \mathrm{bw}$ ). The extract of $J$. adhatoda displayed moderate hypoglycemic activity with the reduction of blood glucose level of $33.71 \%$. The main mechanism of causing hyperglycemia is the reduction of glucose utilization by the tissues and overproduction of glucose by hepatic glycogenolysis and gluconeogenesis. $^{34}$ The plant samples exhibited promising hypoglycemic activity with statistically significant lowering of blood glucose level. The root extracts of A. nilotica and A. inidca reduced the blood

Table 2. Screening of hypoglycemic activity of methanol extracts of the plant roots using glucose tolerance test (GTT).

\begin{tabular}{|c|c|c|c|c|c|c|}
\hline \multirow[t]{2}{*}{ Group } & \multirow{2}{*}{$\begin{array}{l}\text { Dose } \\
(\mathrm{mg} / \mathrm{kg} \mathrm{bw})\end{array}$} & \multicolumn{5}{|c|}{ Blood glucose level $(\mathrm{mmol} / \mathrm{l})$ Mean \pm SEM } \\
\hline & & 0 minute & 30 minute & 60 mins & 90 mins & 120 mins \\
\hline $\begin{array}{l}\text { Control ( } 1 \% \text { Tween- } \\
80 \text { in normal saline) }\end{array}$ & $\begin{array}{l}0.2 \mathrm{ml} / 10 \mathrm{~g} \text { of } \\
\text { body wt }\end{array}$ & $6.72 \pm 0.29$ & $17.04 \pm 0.5$ & $15.42 \pm 0.5$ & $12.44 \pm 0.38$ & $8.84 \pm 0.40$ \\
\hline $\begin{array}{l}\text { Standard } \\
\text { (Glibenclamide) }\end{array}$ & 5 & $6.52 \pm 0.28$ & $10.94 \pm 0.38^{\text {*** }}$ & $7.64 \pm 0.31^{* *}$ & $5.68 \pm 0.16^{* *}$ & $3.76 \pm 0.33^{* *}$ \\
\hline \multirow[t]{2}{*}{ A. nilotica } & 200 & $6.28 \pm 0.19$ & $14.5 \pm 0.34^{*}$ & $12.5 \pm 0.34^{* *}$ & $8.84 \pm 0.25^{* *}$ & $6.08 \pm 0.35^{* *}$ \\
\hline & 400 & $7.00 \pm 0.2$ & $13.4 \pm 0.39^{* *}$ & $10.9 \pm 0.46^{* *}$ & $7.8 \pm 0.39^{* *}$ & $4.98 \pm 0.46^{* *}$ \\
\hline \multirow[t]{2}{*}{ A. indica } & 200 & $7.0 \pm 0.33$ & $15.5 \pm 0.45$ & $13.4 \pm 0.36^{*}$ & $10.42 \pm 0.38^{* *}$ & $6.8 \pm 0.39^{*}$ \\
\hline & 400 & $6.46 \pm 0.24$ & $12.42 \pm 0.32^{* *}$ & $10.08 \pm 0.38^{* *}$ & $7.58 \pm 0.29 * *$ & $5.52 \pm 0.46^{* *}$ \\
\hline \multirow[t]{2}{*}{ J. adhatoda } & 200 & $6.18 \pm 0.35$ & $13.06 \pm 0.45^{* *}$ & $11.32 \pm 0.35^{\text {** }}$ & $9.52 \pm 0.37^{* *}$ & $7.68 \pm 0.26$ \\
\hline & 400 & $6.76 \pm 0.17$ & $11.52 \pm 0.33^{* * *}$ & $9.96 \pm 0.20^{* *}$ & $7.98 \pm 0.23^{* *}$ & $5.86 \pm 0.19^{\text {** }}$ \\
\hline
\end{tabular}

$\overline{\mathrm{SEM}}=$ Standard Error of Mean; One-way ANOVA; $* *=$ statistically highly significant where $\mathrm{P}<0.001, *=$ statistically significant where $\mathrm{P}<0.05$; Probability values calculated as compared to control using one way ANOVA followed by Dunnett's test using SPSS 19 program 


\section{$\%$ Fall of blood sugar level}

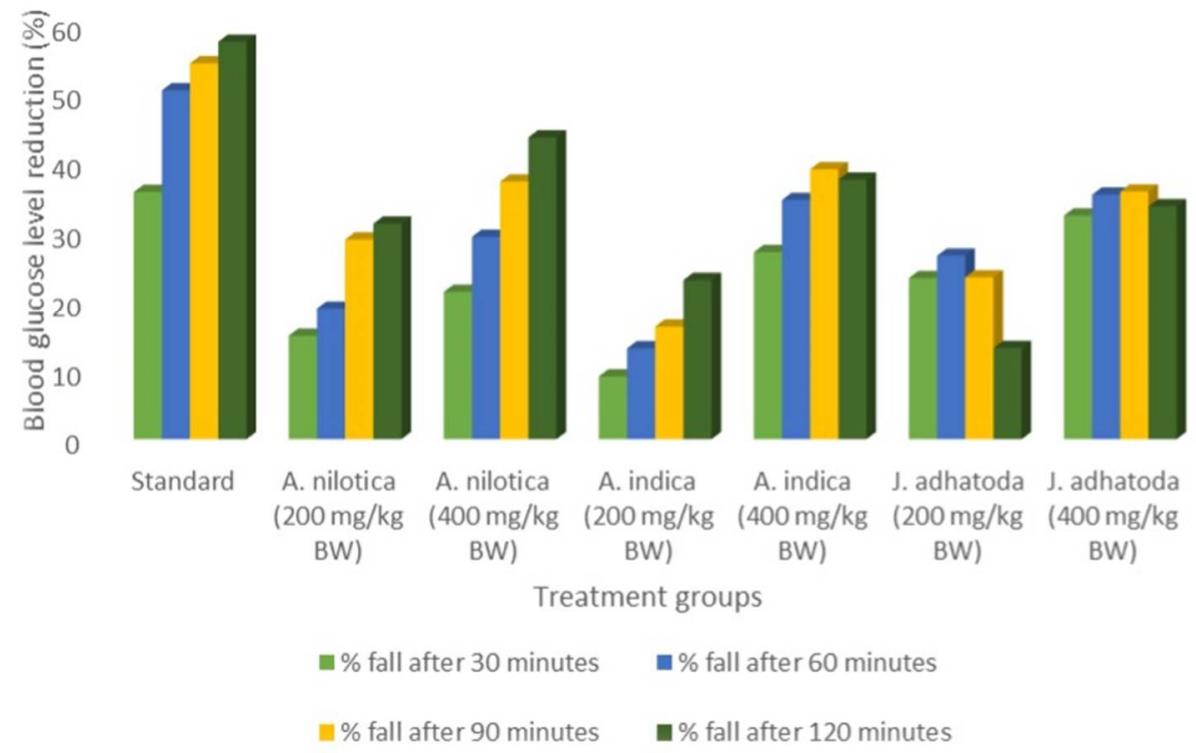

Figure 1. Comparative study of fall of percentage of blood glucose level by standard (Glibenclamide) and crude methanol extracts of $A$. nilotica, A. indica and J. adthatoda roots compared to control.

glucose level to normal at the dose of $200 \mathrm{mg} / \mathrm{kg}$ bw after 120 minutes of administration in the glucose loaded mice. J. adhatoda root extract showed reduction of blood glucose to normal level at the dose of $400 \mathrm{mg} / \mathrm{kg}$ bw after 120 minutes of administration. All the plant extracts reduced blood sugar level in a dose dependent manner. This indicates the improvement of external glucose utilizing capacity of the animals under the influence of the plant extracts which is comparable to the glucose lowering activity of the standard glibenclamide. So, it suggests that the plant root extracts may have a similar mechanism of action as the sulphonylureas to exert hypoglycemic activity. ${ }^{35}$ Phytoconstituents present in the plant roots are responsible for these activities which should be identified for developing an effective therapeutic agent.

Molecular docking analysis. COX-1 and COX2 enzymes catalyzes the rate limiting step in the formation of prostaglandins from arachidonic acid and so, these enzymes were selected for predicting the anti-nociceptive activity of the selected phytoconstituents by analyzing their binding affinity in the active sites of the enzymes compared to standard diclofenac. All of the tested compounds except nimbin revealed significant binding affinity towards the target enzymes $(-6.6$ to $-8.7 \mathrm{kcal} / \mathrm{mol}$ ) (Table 3 ). Among all the compounds, flavan-3-ol showed the highest binding affinity for both enzymes (-8.6 and $8.7 \mathrm{kcal} / \mathrm{mol})$ compared to standard diclofenac $(-8.3$ and $-7.8 \mathrm{kcal} / \mathrm{mol}$ ) (Table 4, Table 5). Flavan-3-ol exhibited strong affinity towards the active site of COX-1 by forming stable hydrogen bonds with ALA527 residue and strong amide pi-stacked bonds with GLY526 and ALA527 (Figure 2). The compounds also shared similar hydrophobic interaction sites with diclofenac at amino acids positions VAL349 and ALA527 of the COX-1 receptor which indicate that flavan-3-ol is binding to the same pocket of COX-1 enzyme target site but with a stronger affinity than diclofenac. Even better results were observed in case of COX-2 receptor where flavan-3-ol had much higher docking scores compared to diclofenac mainly because of two strong hydrogen bonds formed with VAL349 and ALA527 residues, respectively (Figure 3 ). Both diclofenac and 
flavan-3-ol showed binding to the same pocket of COX-2 receptor which is evident in the similar hydrophobic interactions seen with both these ligands at VAL349, ALA527, LEU531, LEU352 and VAL523 residues of the receptor.

ATP-sensitive potassium channel with SUR1 subunit was utilized for predicting hypoglycemic activity of the selected compounds compared to standard glibenclamide. Among all the tested compounds, quercetin showed the highest binding affinity with the receptor $(-8.8 \mathrm{kcal} / \mathrm{mol})$ (Table 6). All other compounds showed less binding affinity (ranging from -5.7 to $-8.3 \mathrm{kcal} / \mathrm{mol}$ ) (Table 3) than glibenclamide (-9.3 $\mathrm{kcal} / \mathrm{mol}) . \quad$ Quercetin demonstrated docking with the target receptor by forming strong conventional hydrogen bonds with ARG306, ARG1246 and ARG1246 residues whereas glibenclamide showed docking with active site of the receptor forming conventional hydrogen bonds with ARG306, ARG370 and ASN1273 residues which is comparable to the binding interactions of quercetin (Figure 4). Both glibenclamide and quercetin have similar interaction with ARG306, ALA380 and PRO436 residues of the target receptor which indicates that they are binding to the SUR1 subunit target site.

Table 3. Binding affinities of standard ligands and selected compounds against target proteins.

\begin{tabular}{|c|c|c|c|}
\hline \multirow{3}{*}{ Compounds } & \multicolumn{3}{|c|}{ Binding affinity (Kcal/mol) } \\
\hline & \multicolumn{2}{|c|}{ Analgesic activity } & \multirow{2}{*}{$\begin{array}{c}\text { Hypoglycemic activity } \\
\text { SUR1 (5YW7) } \\
\end{array}$} \\
\hline & COX1 (1EQG) & COX-2 (5IKT) & \\
\hline Standard & -8.3 & -7.8 & -9.3 \\
\hline Catechin & -6.7 & -7.8 & -8.3 \\
\hline Ethyl gallate & -6.5 & -6.3 & -5.7 \\
\hline Flavan-3-ol & -8.6 & -8.7 & -8.3 \\
\hline Nimbin & 4.2 & 7 & -8.3 \\
\hline Quercetin & -6.6 & -8.2 & -8.8 \\
\hline Vasicine & -7.4 & -7.5 & -6.8 \\
\hline Vasicinol & -6.8 & -6.9 & -6.8 \\
\hline Vasicinone & -7.7 & -8.1 & -7.3 \\
\hline
\end{tabular}

Standard ligands for cyclooxygenase-1 (PDB: 1EQG) and cyclooxygenase-2 (PDB: 5IKT) is diclofenac (PubChem CID 3033). For pancreatic ATP-sensitive potassium channel with SUR1 subunit (PDB: 5YW7) the standard ligand is glibenclamide (PubChem CID 3488).

Table 4. Comparison of binding interactions of standard and the eompound with best binding affinity against cyclooxygenase-1 (PDB: 1EQG).

\begin{tabular}{|c|c|c|c|c|c|c|c|c|c|}
\hline \multirow[t]{2}{*}{ Compounds } & \multirow{2}{*}{$\begin{array}{l}\text { Binding } \\
\text { energy } \\
(\mathrm{Kcal} / \mathrm{mol})\end{array}$} & \multicolumn{4}{|c|}{ Hydrophobic Interactions } & \multicolumn{4}{|c|}{ Hydrogen bond } \\
\hline & & $\begin{array}{l}\text { Bonding } \\
\text { type }\end{array}$ & $\begin{array}{l}\text { Interacting } \\
\text { amino acids }\end{array}$ & $\begin{array}{l}\text { Interacting } \\
\text { atoms or } \\
\text { rings }\end{array}$ & $\begin{array}{c}\text { Distance } \\
(\AA)\end{array}$ & $\begin{array}{l}\text { Bonding } \\
\text { type }\end{array}$ & $\begin{array}{l}\text { Interacting } \\
\text { amino acids }\end{array}$ & $\begin{array}{c}\text { Interacting } \\
\text { atoms or } \\
\text { rings }\end{array}$ & $\begin{array}{l}\text { Distance } \\
(\AA)\end{array}$ \\
\hline \multirow[t]{10}{*}{ Diclofenac } & -8.3 & $\begin{array}{l}\text { Pi-Pi T- } \\
\text { shaped }\end{array}$ & TRP387 & Benzene & 4.957 & $\begin{array}{c}\text { Conven- } \\
\text { tional }\end{array}$ & SER530 & H... O & 2.261 \\
\hline & & Alkyl & VAL349 & $\mathrm{Cl}$ & 4.278 & & & & \\
\hline & & & LEU352 & $\mathrm{Cl}$ & 5.167 & & & & \\
\hline & & & MET522 & $\mathrm{Cl}$ & 4.944 & & & & \\
\hline & & & ILE523 & $\mathrm{Cl}$ & 4.296 & & & & \\
\hline & & Pi-Alkyl & TYR348 & $\mathrm{Cl}$ & 4.857 & & & & \\
\hline & & & PHE518 & $\mathrm{Cl}$ & 4.033 & & & & \\
\hline & & & VAL349 & Benzene & 5.157 & & & & \\
\hline & & & ILE523 & Benzene & 4.146 & & & & \\
\hline & & & ALA527 & Benzene & 4.825 & & & & \\
\hline \multirow[t]{4}{*}{ Flavan-3-ol } & -8.6 & $\begin{array}{l}\text { Amide-Pi } \\
\text { Stacked }\end{array}$ & $\begin{array}{l}\text { GLY526; } \\
\text { ALA527 }\end{array}$ & Benzene & 3.949 & Carbon & ALA527 & $\mathrm{H} . . . \mathrm{O}$ & 2.572 \\
\hline & & Pi-Alkyl & VAL349 & Benzene & 4.487 & & & & \\
\hline & & & ALA527 & Benzene & 4.027 & & & & \\
\hline & & & LEU531 & Benzene & 5.228 & & & & \\
\hline
\end{tabular}




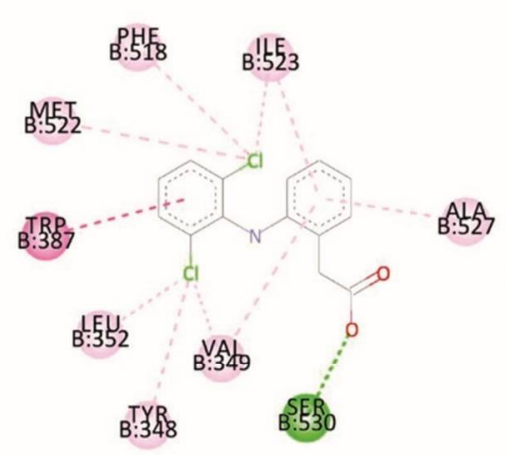

a)

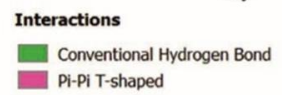

Conventional Hydrogen Bond
Pi-Pi T-shaped

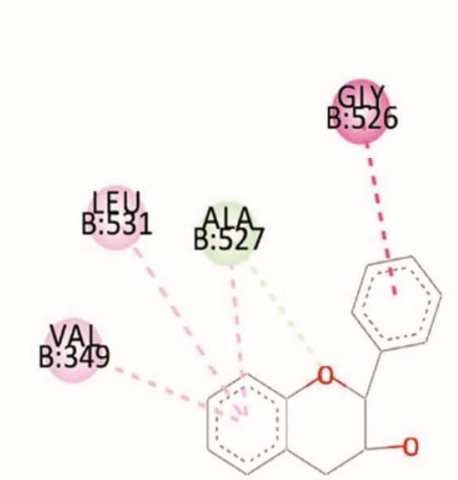

d)

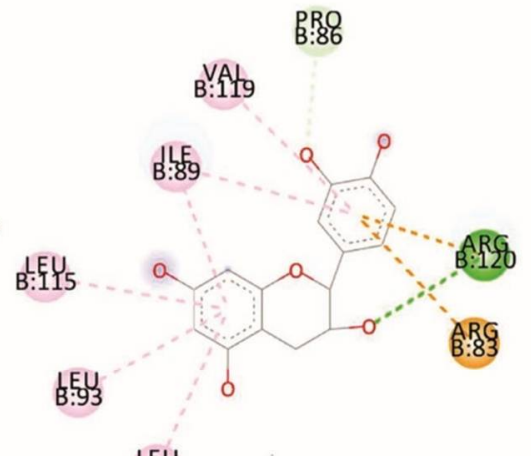

b)
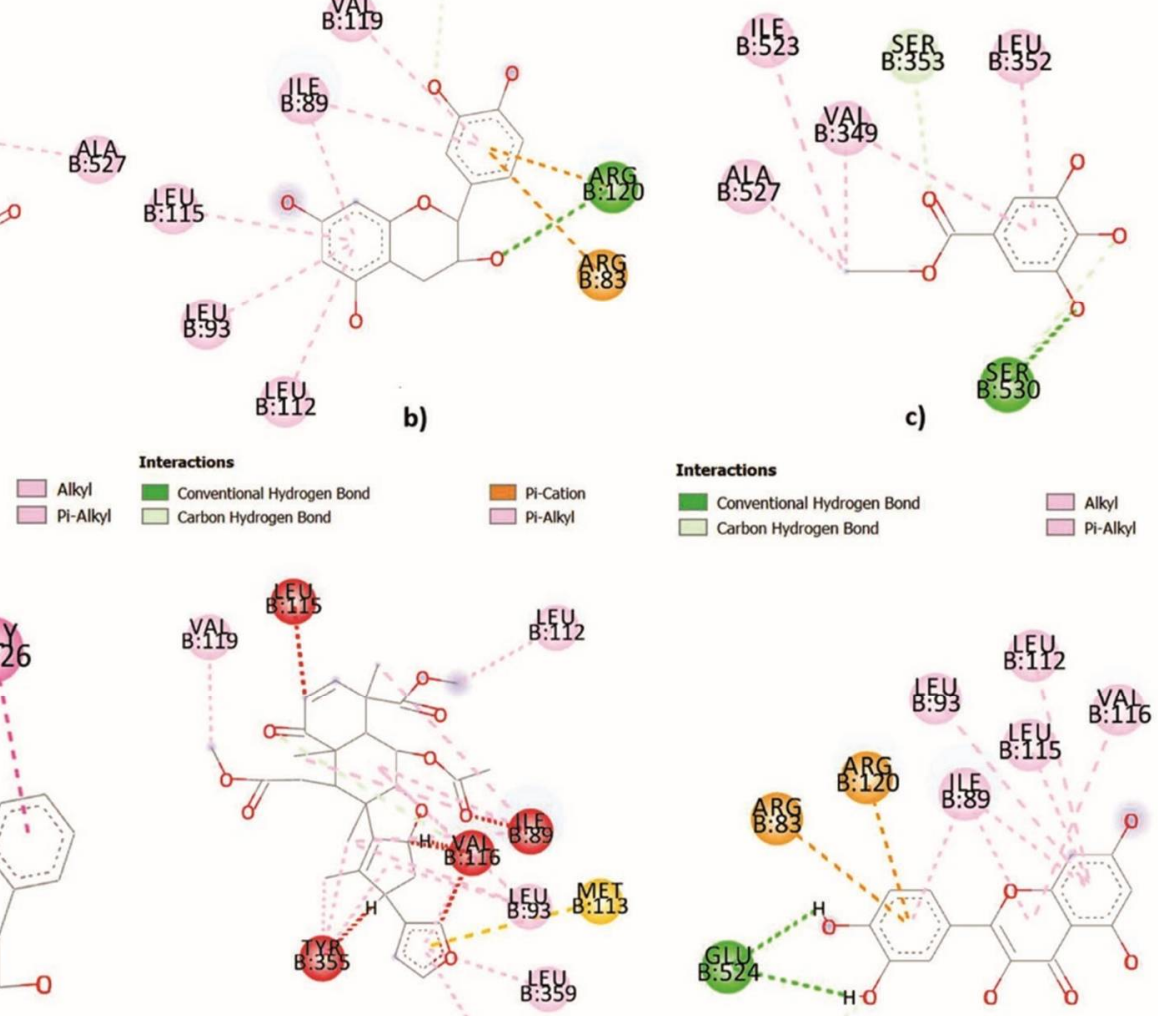

e) $\quad$ B:5 531
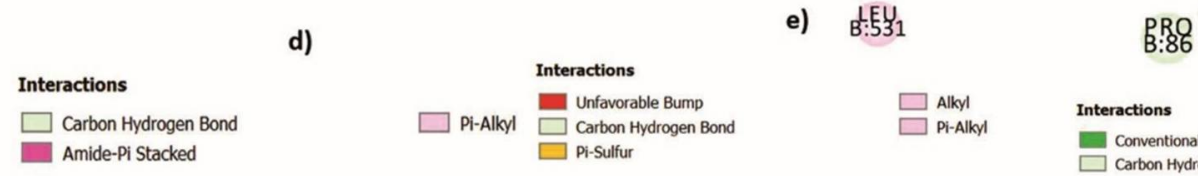

f)

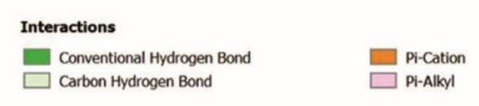

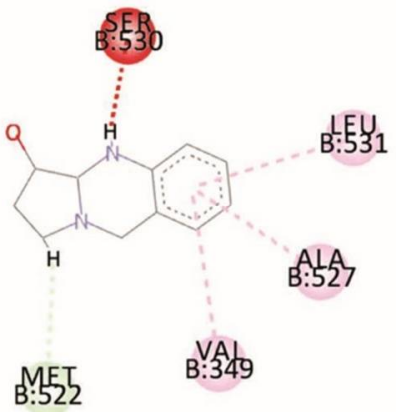

g)

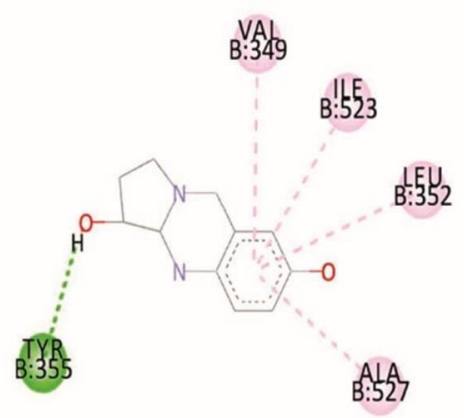

h)

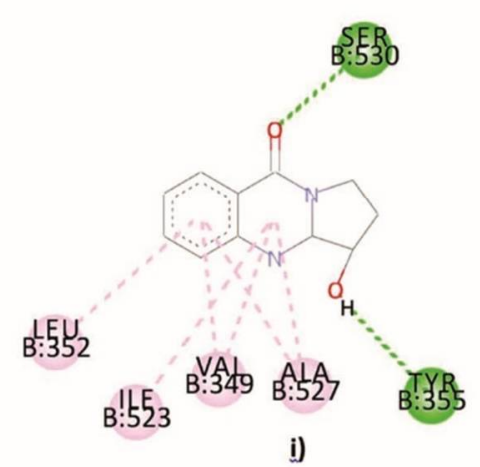

Interactions Conventional Hydrogen Bond $\square$ Carbon Hydrogen Bond

Figure 2. Binding interactions of a) diclofenac, b) catechin, c) ethyl gallate, d) flavan-3-ol, e) nimbin, f) quercetin, g) vasicine h) vasicinol i) vasicinone with $1 \mathrm{EQG}$. 


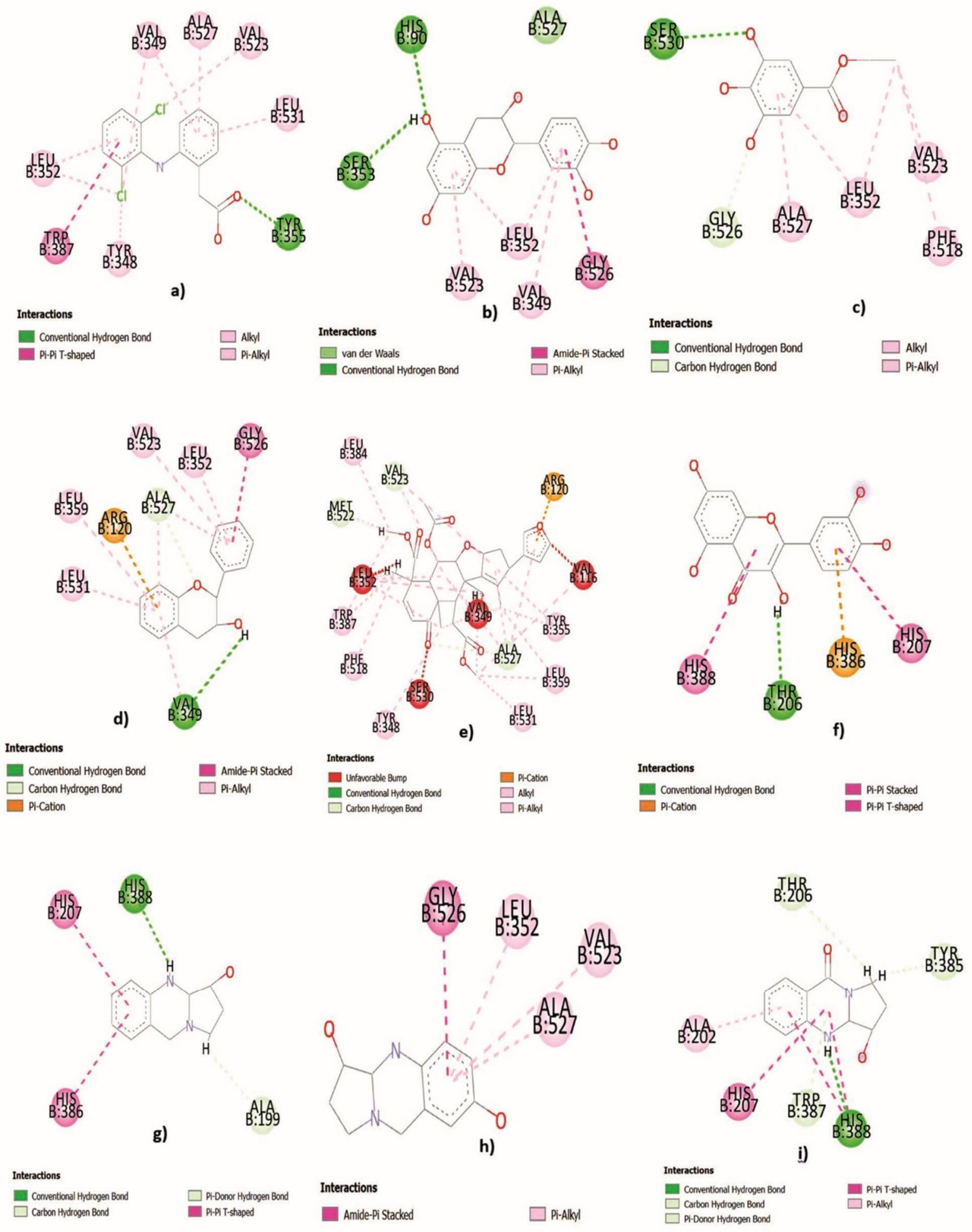

Figure 3. Binding interactions of a) diclofenac, b) catechin, c) ethyl gallate, d) flavan-3-ol, e) nimbin, f) quercetin, g) vasicine h) vasicinol i) vasicinone with 5IKT. 

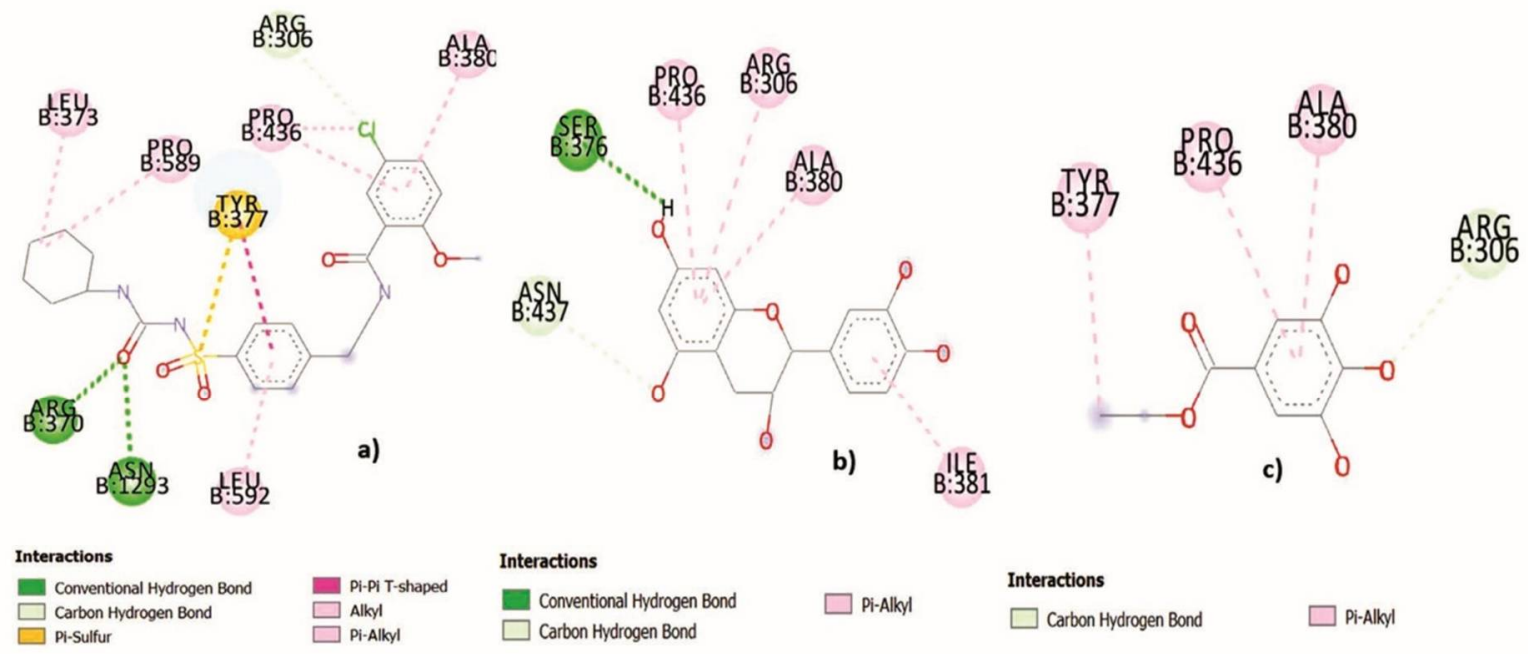

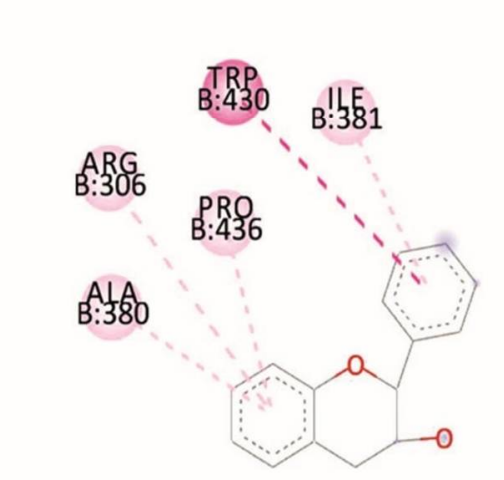

d)

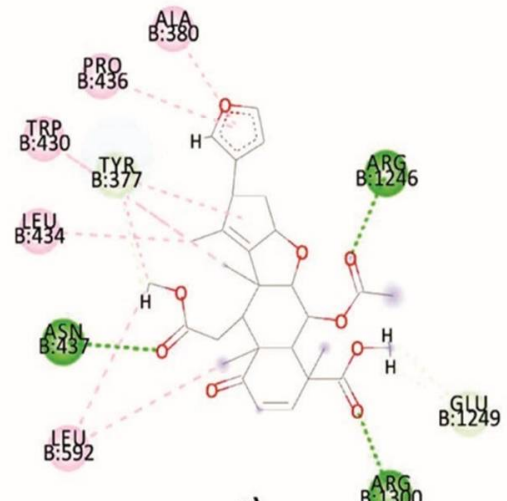

e)

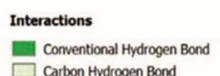

B 1300

吕 Ally $\square$ Carbon Hydrogen Bond

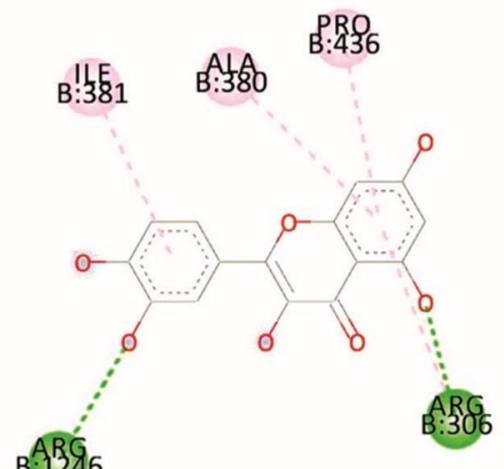

f)

Interactions

Pi-Pi T-shaped

$\square$ Pi-Alkyl

Interactions
$\square$ Conventional Hydrogen Bond $\quad \square$ Pi-Alkyl

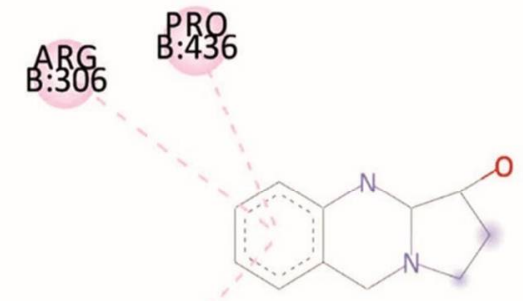

B: 380

g)

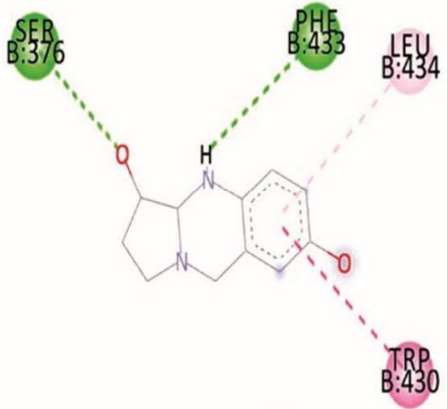

h)

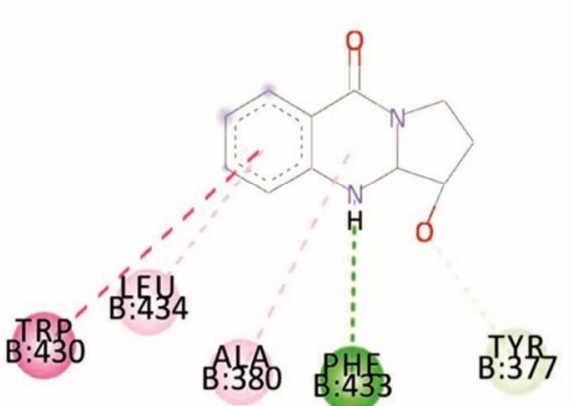

i)

Interactions

$\square$ Pi-Alkyl

Interactions

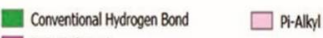

Pi-Pi T-shaped

Interactions

Conventional Hydrogen Bond $\square$ Carbon Hydrogen Bond

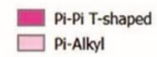

Figure 4. Binding interactions of a) glibenclamide, b) catechin, c) ethyl gallate, d) flavan-3-ol, e) nimbin, f) quercetin, g) vasicine h) vasicinol i) vasicinone with 5 YW7. 
Table 5. Comparison of binding interactions of standard and the compound with best binding affinity against cyclooxygenase-2 (PDB: 5IKT).

\begin{tabular}{|c|c|c|c|c|c|c|c|c|c|}
\hline \multirow[t]{2}{*}{ Compounds } & \multirow{2}{*}{$\begin{array}{l}\text { Binding } \\
\text { anergy } \\
(\mathrm{Kcal} / \mathrm{mol})\end{array}$} & \multicolumn{4}{|c|}{ Hydrophobic interactions } & \multicolumn{4}{|c|}{ Hydrogen bond } \\
\hline & & $\begin{array}{c}\text { Bonding } \\
\text { type }\end{array}$ & $\begin{array}{c}\text { Interacting } \\
\text { amino } \\
\text { acids }\end{array}$ & $\begin{array}{l}\text { Interacting } \\
\text { atoms or } \\
\text { rings }\end{array}$ & $\begin{array}{c}\text { Distance } \\
(\AA)\end{array}$ & Bonding type & $\begin{array}{l}\text { Interacting } \\
\text { amino acids }\end{array}$ & $\begin{array}{l}\text { Interacting } \\
\text { atoms or } \\
\text { rings }\end{array}$ & $\begin{array}{c}\text { Distance } \\
(\AA)\end{array}$ \\
\hline \multirow[t]{9}{*}{ Diclofenac } & -7.8 & $\begin{array}{l}\text { Pi-Pi T- } \\
\text { shaped }\end{array}$ & TRP387 & Benzene & 5.44 & Conventional & TYR355 & H...O & 2.417 \\
\hline & & Pi-Alkyl & TYR348 & Benzene & 5.182 & & & & \\
\hline & & & VAL349 & Benzene & 3.944 & & & & \\
\hline & & & ALA527 & Benzene & 3.519 & & & & \\
\hline & & & LEU531 & Benzene & 4.976 & & & & \\
\hline & & & LEU352 & Benzene & 5.277 & & & & \\
\hline & & Alkyl & VAL349 & $\mathrm{Cl}$ & 4.575 & & & & \\
\hline & & & LEU352 & $\mathrm{Cl}$ & 5.121 & & & & \\
\hline & & & VAL523 & $\mathrm{Cl}$ & 3.463 & & & & \\
\hline \multirow[t]{9}{*}{ Flavan-3-ol } & -8.7 & Pi-Cation & ARG120 & Benzene & 4.94 & Conventional & VAL349 & H... O & 3.085 \\
\hline & & $\begin{array}{l}\text { Amide-Pi } \\
\text { Stacked }\end{array}$ & $\begin{array}{l}\text { GLY526; } \\
\text { ALA527 }\end{array}$ & Benzene & 4.33 & & & & \\
\hline & & Pi-Alkyl & VAL349 & Benzene & 4.616 & & & & \\
\hline & & & LEU359 & Benzene & 5.469 & & & & \\
\hline & & & ALA527 & Benzene & 4.354 & & & & \\
\hline & & & LEU531 & Benzene & 5.181 & Carbon & ALA527 & H... O & 2.907 \\
\hline & & & LEU352 & Benzene & 4.890 & & & & \\
\hline & & & VAL523 & Benzene & 5.131 & & & & \\
\hline & & & ALA527 & Benzene & 4.875 & & & & \\
\hline
\end{tabular}

Table 6. Comparison of binding interactions of standard and the compound with best binding affinity against the pancreatic ATPsensitive potassium channel with SUR1 subunit (PDB: 5YW7) receptor.

\begin{tabular}{|c|c|c|c|c|c|c|c|c|c|}
\hline \multirow[t]{2}{*}{ Compounds } & \multirow{2}{*}{$\begin{array}{l}\text { Binding } \\
\text { energy } \\
(\mathrm{Kcal} / \mathrm{mol})\end{array}$} & \multicolumn{4}{|c|}{ Hydrophobic interactions } & \multicolumn{4}{|c|}{ Hydrogen bond } \\
\hline & & $\begin{array}{l}\text { Bonding } \\
\text { type }\end{array}$ & $\begin{array}{l}\text { Interacting } \\
\text { amino } \\
\text { acids }\end{array}$ & $\begin{array}{c}\text { Interacting } \\
\text { atoms or rings }\end{array}$ & $\begin{array}{c}\text { Distance } \\
(\AA)\end{array}$ & Bonding type & $\begin{array}{l}\text { Interacting } \\
\text { amino acids }\end{array}$ & $\begin{array}{l}\text { Interacting } \\
\text { atoms or } \\
\text { rings }\end{array}$ & $\begin{array}{c}\text { Distance } \\
(\AA)\end{array}$ \\
\hline \multirow[t]{9}{*}{ Glibenclamide } & -9.3 & Pi-Sulfur & TYR377 & S & 5.87 & Conventional & ARG370 & H...O & 2.063 \\
\hline & & $\begin{array}{l}\text { Pi-Pi T- } \\
\text { shaped }\end{array}$ & TYR377 & Benzene & 5.274 & & & & \\
\hline & & Alkyl & PRO589 & Cyclohexane & 5.363 & & ASN1293 & H... O & 2.927 \\
\hline & & & LEU373 & Cyclohexane & 5.256 & & & & \\
\hline & & & ARG306 & $\mathrm{Cl}$ & 3.69 & Carbon & ARG306 & $\mathrm{H} . . . \mathrm{Cl}$ & 3.07 \\
\hline & & & PRO436 & $\mathrm{Cl}$ & 3.66 & & & & \\
\hline & & Pi-Alkyl & LEU592 & Benzene & 5.451 & & & & \\
\hline & & & ALA380 & Benzene & 4.979 & & & & \\
\hline & & & PRO436 & Benzene & 5.318 & & & & \\
\hline \multirow[t]{4}{*}{ Quercetin } & -8.8 & Pi-Alkyl & ILE381 & Benzene & 5.314 & Conventional & ARG306 & H...O & 2.188 \\
\hline & & & ARG306 & Benzene & 4.733 & & ARG1246 & $\mathrm{H} \ldots \mathrm{O}$ & 2.704 \\
\hline & & & ALA380 & Benzene & 4.551 & & ARG1246 & H...O & 2.777 \\
\hline & & & PRO436 & Benzene & 5.176 & & & & \\
\hline
\end{tabular}


Table 7. In silico prediction of physicochemical properties of the test compounds for good oral bioavailability.

\begin{tabular}{llllllll}
\hline Compounds & $\begin{array}{l}\text { Molecular weight } \\
\text { (M.W) }(\mathrm{g} / \mathrm{mol})\end{array}$ & $\begin{array}{l}\text { H-bond } \\
\text { acceptors }\end{array}$ & $\begin{array}{l}\text { H-bond } \\
\text { donors }\end{array}$ & $\begin{array}{l}\text { Molar } \\
\text { refractivity }\end{array}$ & $\begin{array}{l}\text { Lipophilicity } \\
\text { logP }(\mathrm{o} / \mathrm{w})\end{array}$ & $\begin{array}{l}\text { No. of } \\
\text { violations }\end{array}$ & $\begin{array}{l}\text { GI } \\
\text { absorption }\end{array}$ \\
\hline Diclofenac & 296.15 & 2 & 2 & 77.55 & 3.66 & 0 & High \\
Glibenclamide & 494.0 & 5 & 3 & 126.25 & 3.58 & 0 & Low \\
Catechin & 290.27 & 6 & 5 & 74.33 & 0.85 & 0 & High \\
Ethyl gallate & 198.17 & 5 & 3 & 48.6 & 0.92 & 0 & High \\
Flavan-3-ol & $226 . .27$ & 2 & 1 & 66.24 & 2.66 & 0 & High \\
Nimbin & 540.6 & 9 & 0 & 138.81 & 3.24 & 1 & High \\
Quercetin & 302.24 & 7 & 5 & 78.03 & 1.23 & 0 & High \\
Vasicine & 188.23 & 2 & 1 & 62.11 & 1.17 & 0 & High \\
Vasicinol & 204.23 & 3 & 2 & 64.13 & 0.77 & 0 & High \\
Vasicinone & 202.21 & 3 & 1 & 56.09 & 0.94 & 0 & High \\
\hline
\end{tabular}

In silico ADME analysis. In silico physicochemical properties like molecular weight, H-bond donors and acceptors, molar refractivity, lipophilicity $\log$, GI absorption etc. were predicted by Swiss ADME analysis. All the tested compounds showed good GI absorption and acceptable lipophilicity $\log \mathrm{P}$ values ranging from 0.77 to 3.24 for drug like activities (Table 7). Apart from nimbin, the other seven tested molecules did not violate Lipinski's rule of 5 which makes them potential candidates for new drug development by further SAR analysis.

\section{CONCLUSION}

From this preliminary study it is evident that the crude methanolic root extracts of the three plants have significant analgesic and hypoglycemic properties. In silico analysis of some phytoconstituents of these plants showed promising results in prediction of their binding affinities with the target receptors/enzymes and drug like physicochemical properties. So, further extensive studies are encouraged on isolating chemical constituents from these plants to identify the chemical components accountable for these significant pharmacological actions as well as exploration of these results on higher animal models.

\section{CONFLICT OF INTEREST}

The authors declare that they do not have any conflict of interests.

\section{CONTRIBUTION OF AUTHORS}

The whole experiment was designed and supervised by SMAR. FH performed the experiments and MSH analyzed the experimental data. PS performed the literature review and FH and PS wrote down the manuscript. FIR performed the in silico studies and molecular docking. All authors have read and approved the manuscript.

\section{ACKNOWLEDGEMENTS}

The authors express their gratitude to Jahangirnagar University for supplying the laboratory animals used in the study and to Institute of Nutrition and Food Science (INFS), University of Dhaka, Bangladesh for providing animal house throughout the experiment. The research was financially supported by Ministry of Science, Information and Communication Technology, Government of the People's Republic of Bangladesh.

\section{REFERENCES}

1. Bhushan, M., Rao, C.V., Ojha, S.K., Vijayakumar, M. and Verma, A. 2010. An analytical review of plants for antidiabetic activity with their phytoconstituents and mechanism of action. Int. J. Pharm. Sci. Res. 1, 29-46.

2. Kathe, W. 2006. In: Medicinal and Aromatic Plants (Bogers, R.J., Craker, L.E. and Lange, D, Eds.), Springer, London, Chapter 8, pp. 109-120.

3. Council of Scientific \& Industrial Research (India). 1971. The Wealth of India, a dictionary of Indian raw materials and industrial products. Publications \& Information Directorate, CSIR, New Delhi. 
4. Elisabetsky, E. 1991. Sociopolitical, economical and ethical issues in medicinal plant research. J. Ethnopharmacol. 32, 235-239.

5. Hussain, F., Poddar, S.K., Ganguly, A. and Rahman, S.M.A. 2016. Investigation of CNS depressant, anti-diarrheal and cytotoxic activities of crude methanolic extracts of Acacia nilotica and Justicia adhatoda root. Indo. Am. J. Pharm. Res. 6, 3954-3961.

6. Ganguly, A., Mahmud, Z.A., Saha, S.K. and Rahman, S.M.A. 2016. Evaluation of antinociceptive and antidiarrhoeal properties of Manilkara zapota leaves in Swiss albino mice. Pharm. Biol. 54, 1413-1419.

7. Noor, S., Rahman, S.M.A., Ahmed, Z., Das, A. and Hossain, M.M. 2013. Evaluation of anti-inflammatory and antidiabetic activity of ethanolic extracts of Desmodium pulchellum Benth. (Fabaceae) barks on albino wistar rats. J. Appl. Pharm. Sci. 3, 48-51.

8. Hussain, F., Ganguly, A., Hossain, M.S. and Rahman, S.M.A. 2014. Analgesic and anti-diarrhoeal activities of lagerstroemia speciosa roots in experimental animal model. Dhaka Univ. J. Pharm. Sci. 13, 57-62.

9. Malviya, S., Rawat, S., Kharia, A. and Verma, M. 2011. Medicinal attributes of Acacia nilotica Linn.-A comprehensive review on ethnopharmacological claims. Int. J. Pharm. Life Sci. 2, 830-837.

10. Hashmat, I., Azad, H. and Ahmed, A. 2012. Neem (Azadirachta indica A. Juss)-A Nature's Drugstore: An overview. Int. Res. J. Biol. Sci. 1, 76-79.

11. Vasantharaj, S., Sathiyavimal, S. and Hemashenpagam, N. 2013. Phytochemical analysis and antibacterial activity of Azadirachta indica. Int. J. Pharm. Sci. Rev. Res. 22, 59-61.

12. Gulfraz, M., Arshad, M., Nayyer, N., Kanwal, N. and Nisar, U. 2004. Investigation for Bioactive Compounds of Berberis Lyceum Royle and Justicia Adhatoda L. Ethnobot. Leafl. 2004, 5 .

13. Corrêa, G.M. and de Alcântara, A.F.C. 2011. Chemical constituents and biological activities of species of justicia -a review. Rev. Bras. Farmacogn. 22, 220-238.

14. Jain, S.K. 1991. Dictionary of Indian Folk Medicine and Ethnobotany. Deep Publications, New Delhi.

15. Dhankar, S., Kaur, R., Ruhil, S., Balhara, M., Dhankar, S. and Chhillar, A.K. 2011. A review on Justicia adhatoda: a potential source of natural medicine. African J. Plant Sci. 5, 620-627.

16. Drabu, S., Khatri, S., Babu and S. 2012. Neem: Healer of All Ailments. Res. J. Pharm. Biol. Chem. Sci. 3, 120-126.

17. Ali, A., Akhtar, N., Khan, B. A., Khan, M. S., Rasul, A., Khalid, N., Khalid, W., Mahmood, T., and Ali, L. 2012. Acacia nilotica: A plant of multipurpose medicinal uses. Artic J. Med. Plants. 6, 1492-1496.

18. Atkovska, K., Samsonov, S.A., Paszkowski-Rogacz, M. and Pisabarro, M.T. 2014. Multipose binding in molecular docking. Int. J. Mol. Sci. 15, 2622-2645.

19. Koster, R. 1959. Acetic acid for analgesic screening. Fed. Proc. 18, 412.

20. Ahmed, M., Shikha, H.A., Sadhu, S.K., Rahman, M.T. and Datta, B.K. 2001. Analgesic, diuretic, and anti-inflammatory principle from Scoparia dulcis. Pharmazie. 56, 657-660.
21. Babu, V., Gangadevi, T. and Subramoniam, A. 2002. Antihyperglycaemic activity of Cassia kleinii leaf extract in glucose fed normal rats and alloxan-induced diabetic rats. Indian J. Pharmacol. 34, 409-415.

22. Fröde, T.S., Medeiros, Y.S. 2008. Animal models to test drugs with potential antidiabetic activity. J. Ethnopharm. 115, 173 183.

23. Bergmeyer, H.U. 1965. Principles of Enzymatic Analysis. In: Methods of Enzymatic Analysis (Bergmeyer, H.U., ed.) Verlag Chemie, Weinheim, pp. 736-743.

24. Berman, H.M., Westbrook, J., Feng, Z., Gilliland, G., Bhat, T.N., Weissig, H., Shindyalov, I.N, and Bourne, P.E. 2000. The Protein Data Bank. Nucleic Acids Res. 28, 235-242.

25. Xu, S., Hermanson, D.J., Banerjee, S., Ghebreselasie, K., Clayton, G.M., Garavito, R.M., and Marnett, L.J. 2014. Oxicams bind in a novel mode to the cyclooxygenase active site via a two-water-mediated h-bonding network. J. Biol. Chem. 289, 6799-6808.

26. Orlando, B.J. and Malkowski, M.G. 2016. Substrate-selective inhibition of cyclooxygeanse-2 by fenamic acid derivatives is dependent on peroxide tone. J. Biol. Chem. 291, 15069-15081.

27. Reynaldi, M.A., Riza, H. and Luliana, S. 2018. Docking study of allicin with sulfonylurea receptor 1 , complex 1 and ppary receptor on insulin resistance. Int. J. Pharm. Pharm. Sci. 10 , 130.

28. Delano, L.W. 2002. The PyMOL Molecular Graphics System. Available at: http://www.pymol.org.

29. Guex, N. and Peitsch, M.C. 1997. SWISS-MODEL and the Swiss-PdbViewer: An environment for comparative protein modeling. Electrophoresis. 18, 2714-2723.

30. Trott, O. and Olson, A.J. 2009. AutoDock Vina: Improving the speed and accuracy of docking with a new scoring function, efficient optimization, and multithreading. $J$. Comput. Chem. 31, 455-461.

31. Zulfiker, A., Rahman, M.M., Hossain, M.K., Hamid, K., Mazumder, M. and Rana, S. 2010. In vivo analgesic activity of ethanolic extracts of two medicinal plants-Scoparia dulcis L. and Ficus racemosa Linn. Biol. Med. 2, 42-48.

32. Zakaria, Z.A., Ghani, Z.D.F.A., Raden, R.N.S., Gopalan, H.K., Sulaiman, M.R., Mat Jais A.M, Somchit, M.N., Kader, A.A., and Ripin, J. 2008. Antinociceptive, anti-inflammatory, and antipyretic properties of an aqueous extract of Dicranopteris linearis leaves in experimental animal models. J. Nat. Med. 62, 179-187.

33. Ribeiro, R.A., Vale, M.L., Thomazzi, S.M., Paschoalato, A.B.P., Poole, S., Ferreira, S.H., and Cunha, F.Q. 2000. Involvement of resident macrophages and mast cells in the writhing nociceptive response induced by zymosan and acetic acid in mice. Eur. J. Pharmacol. 387, 111-118.

34. Maithili, V., Dhanabal, S.P., Mahendran, S. and Vadivelan, R. 2011. Antidiabetic activity of ethanolic extract of tubers of Dioscorea alata in alloxan induced diabetic rats. Indian $J$. Pharmacol. 43, 455.

35. Sachdewa, A., Nigam, R. and Khemani, L.D. 2001. Hypoglycemic effect of Hibiscus rosa sinensis L. leaf extract in glucose and streptozotocin induced hyperglycemic rats. Indian J. Exp. Biol. 39, 284-286. 